\title{
Endowment as an Educational Fundraising Tool for Entrepreneurial University: the U.S. Experience versus Ukrainian Reality and Perspectives
}

KEYWORDS

endowment, educational fundraising, university mission, triple helix, higher education

\begin{abstract}
Krasulia Alla, Endowment as an Educational Fundraising Tool for Entrepreneurial University: the U.S. Experience versus Ukrainian Reality and Perspectives [Obdarzenie (kapitał docelowy) jako sposób pozyskiwania funduszy dla przedsiębiorczego uniwersytetu: amerykańskie doświadczenie a ukraińskie realia i perspektywy]. Kultura - Społeczeństwo - Edukacja nr 2(6) 2014, Poznań 2014, pp. 57-73, Adam Mickiewicz University Press. ISBN 978-83-232-2869-1. ISSN 2300-0422

Educational fundraising could pose significant challenges for Ukrainian universities in times of neoliberal ideology of contemporary educational reforms. The purpose of this paper is to provide an analysis of the best fundraising practices in public US universities in order to implement them in the area of higher education in Ukraine. Examples and data published in a range of educational science journals as well as Ukrainian state laws are analyzed to highlight the purposes, features, and structure of university financial endowments. The article focuses on the "Triple Helix" model as one of the most effective schemes of university development. All things considered it can help Ukrainian universities carry on their social mission, funding various activities relating to education, research, and innovation.
\end{abstract}

Philanthropy in America is the public expression of one's social and civic values. It barters in financial, human and social capital, and empowers common citizens of all financial means to take private action on behalf of community good. Philanthropy is essential to a vibrant democracy because it brings attention to important causes and innovative

remedies for which government and business are often less effective. It ensures community ownership of these remedies and guards against total dominance of "top down" national policies and majority rule.

(Jessica Chao, 2002/2008: 816)

\section{Introduction}

The state of fundraising theory and research, legal trends affecting philanthropy and new patterns of educational fundraising development at global, regional and 
local levels, as well as the comparison of foreign and national teaching experience for the purpose of mutual enrichment of educational cultures can be considered a distinct subject of comparative education research. Fundraising in higher education, as a matter of comparative education research, is interdisciplinary in its nature, as it is placed within the subject fields of three branches of modern higher education theory: university management, innovative teaching and comparative education (in our case it's comparative American studies in higher education) which assumes a multidimensional approach to its research. The analysis of numerous Ukrainian research papers shows that a holistic study, ascertaining the theoretical, contextual and organizational principles of fundraising practices in public US universities, and examining problems of diversification in the funding sources in national Ukrainian higher education, has not been carried out. The relevance and significance of such research is endorsed by the provisions of a wide range of normative documents and regulations of Ukraine, especially such as the Concept of humanitarian development of the Ukrainian state until 2020, Decree of the President of Ukraine "On the National Doctrine of Education Development" (2002), Laws of Ukraine "On Priorities of Innovative Practices in Ukraine" (2012), "On Charity and Charitable Organizations" (1997, 2013), "On Higher Education” (2014), etc. According to the government educational policy Ukrainian universities continue to adopt advanced innovative strategies. The Concept of humanitarian development of the Ukrainian state until 2020 outlines that

... [the] state of humanitarian development in Ukraine is characterized by a combination of contradictory and sometimes opposite orientation processes. On the one hand, according to the reports of the United Nations Development Programme (UNDP) concerning human develo2pment, Ukraine is a country with a relatively high level of human development potential (it takes the $76^{\text {th }}$ position in the Report of 2011), although its ranking varies between the groups of countries with medium and high levels (in 1990 Ukraine ranked the $45^{\text {th }}$ position, and in 2009 the $85^{\text {th }}$ one). On the other hand, it is impossible to deny the acute crisis in the Ukrainian society, caused by difficulties on the way to systemic transformations in the country, as well as worsening of socio-economic situation in the world. Undoubtedly, the process of democratization and market reforms led to the growth of creative thinking and pro-social activity of citizens, the emergence of NGOs, the diversity of market services, in the humanitarian sphere in particular. However, the process of inefficient modernization of the Ukrainian society resulted in manifestations of certain ethical and legislative anomie. In addition, the trend to reduce government involvement supporting the programs related to humanitarian development increases, and as a result the impact of the state on the formation of values and orientations of the population decreases (Концепція гуманітарного розвитку України на період до 2020 року). 
The national interests of Ukraine urgently require it to join the international community, and become an integral and influential European state (Степко М. Ф., Болюбаш Я. Я., та ін., 2003). World experience shows that the success of transformative change in the development of a democratic civil society is impossible without radical changes to the system of education. The cultural and educational integration of Ukraine is one of the priority constituents of the process of joining the international community. Higher education institutions (HEIs) of Ukraine should take an active part in the implementation of this task.

The development of international cooperation should not be an end in itself, as desirable as that end may be. Due to the expansion of international contacts, Ukrainian HEIs not only get access to state-of-the-art technology and efficient teaching techniques in an academic field that enhance the quality of young professionals training. Speedy integration into the world scientific and educational arena, and participation in international educational programs opens the way for Ukrainian universities to various sources of funding, such as research grants, fellowships, academic mobility for students, professors and university staff (Національна стратегія розвитку освіти в Україні на 2012-2021 роки, 2013).

The Bologna Process (The Bologna Process and the European Higher Education Area, The European Higher Education Area in 2012: Bologna Process Implementation Report) has already transformed Ukrainian HE. However, universities in Ukraine are facing enormous challenges ranging from access and accountability, to quality and funding. Among these challenges, financial self-sufficiency seems to be the most critical, as it influences the severity and complexity of other challenges. Consequently, in the context of globalization and neoliberal ideology of contemporary educational reforms, diversification of resources is high on the agenda of university management today. One of the ways to address this challenge is the development of fundraising practices that improve the ability of the HEI to supply resources for the educational, scientific and socially oriented activities of the institution. This practice is new to the national higher education; however, given the recent political and educational conditions in the country and a positive world experience it has significant perspectives for Ukrainian context. As stated in the National Strategy for the Development of Education in Ukraine, for the period 2012-2021 "[the] educational system has to be developed in accordance with contemporary integration and globalization processes, and the requirements of the transition to post-industrial civilization, that will ensure the sustainable development of Ukraine in the first half of the XXI century, and consequently, enable the 
integration of [the] national education system into the European and world educational area" (Національна стратегія розвитку освіти в Україні на 2012-2021 роки, 2013: 87).

The key areas of the national educational policy among the rest of the items listed in the document are as follows: 1) the reformation of the system of education based on humanocentrism or human centered philosophy as a strategy of national education; 2) the upgrade the legislative and regulatory framework of the system of education to meet the requirements of the present time; 3 ) the creation and provision of opportunities for the implementation of various educational models, educational institutions of various types and forms of ownership, and diverse forms and means of obtaining education; 4) the ensuring the availability and accessibility of lifelong learning opportunities; 5) the formation of a healthy educational environment; 6) the development of scientific research and innovative practices in education, and improving the quality of education on the basis of innovation; 7) the informatization of education, including the enrichment of library materials and information resources for education and science; 8) the advancement of teachers' social status; 9) and the creation of contemporary financial and technical foundations for the system of education (Національна стратегія розвитку освіти в Україні на 2012-2021 роки, 2013: 87). Effective implementation of these and other trends of change in the content of higher education requires capital investments by all stakeholders, both public and private. In spite of some positive social changes (democratization, humanization, and the integration into European society) there is still a number of drawbacks in Ukrainian society, for example: 1) the critical state of financial, technical, methodological and informational support of educational institutions; 2) lack of motivation among citizens and businesses to invest in the educational sector; 3 ) underpayment of school teachers and university lecturers; 4) relatively low social status of teachers; 5) corruption in the system of education, ineffective and unjust use of financial and material resources, illegal "squandering" of educational institutions' premises and others. For these and other reasons, the current level of education in Ukraine does not allow it to fully execute the "function of a key resource of socio-economic development and welfare increase of the citizens" (Національна стратегія розвитку освіти в Україні на 2012-2021 роки, 2013: 89); and respectively, the prestige of education and scientific research remains at a very low level in society. In this regard, the modern economics of education aims at the "creation of the necessary prerequisites for the development of all areas of educational field in order to form a high educational level among the people of Ukraine" (Національна доктрина розвитку освіти, 2005). 


\section{Entrepreneurial University Mission}

Given the social transformations of recent decades, higher education is taking an increasingly prioritized position in the public policy of most economically developed countries, as well as among the rapidly developing ones. Every country, wishing to stay in line with global civilizational changes, should pay attention to the situation of its system of higher education: searching for the best ways for those institutions to survive in a crisis; further develop and implement their mission of producing new knowledge, training qualified professionals, offering educational, scientific and cultural services to the society; and strengthening the scientific and economic potential of their region and country. Changes in the labour market cause corresponding changes in education that have been the subject of research not only for experts in this field, but also politicians, philosophers, and administrators. One of the purposes of our research is to analyze the most significant findings of American and Ukrainian researchers on the role of higher education in the context of globalization, and to define the characteristics of a modern university's social mission. American counterparts are able to analyze the problem of university autonomy from "inside", because they work in this environment. Thus, their achievements are valuable for Ukrainian universities in terms of gaining experience.

Post-industrial trends of mass education and culture create an environment where the university has become an active economic participant. In the foreseeable future, neither in Ukraine nor even in the USA, will universities receive state funds sufficient to meet their needs, and to implement the vision and mission of the university. Only the top universities and colleges, the recognized leaders of national education, science and culture of their countries, have stable private or public financial support. Higher education, influenced by processes of globalization, is becoming more decentralized and is spread through regional networks of universities. Their functions include the formation of professional, intellectual, moral, and personal competences which are interconnected by the very idea of the university. The constituents served by the mission of the university imply its dialogic nature, the ability to express its own identity, and to respect the identity of others. The duty of the university is to disseminate knowledge, and prepare society for lifelong learning. Hence there is the need to change the academic culture and reduce its isolation and internal engagement. Public dialogue is an important condition of interaction between the university and its civic environment. An important social and academic issue today is that students are not prepared to solve problems. Soci- 
ety has problems, and universities have courses. Thus, the need for curriculum upgrade is on the agenda nowadays. Yet the transfer of knowledge from universities to society is one-sided. Therefore, an idea of "engaged" university, which appeared in the United States, is gaining more popularity. The principles of its functioning are built on partnership, two-way relations on the basis of mutual respect, and use of resources to meet the needs of the university community. These "involved" universities are able to more quickly respond to changes in society. World practice shows that one of the most effective schemes of university development is to implement tight cooperation according to the "Triple Helix" model, namely "university - industry (business) - government" (see Fig.1) proposed by Henry Etzkowitz (Etzkowitz H., Chunyan Z., 2007). An entrepreneurial university represents a new model of market-oriented academic university. It is more connected with consumers of knowledge that integrate it into the market economy. Thus, the capitalization of knowledge is the foundation of a new mission for the university. In the US the entrepreneurial university exists in terms of the total liability of each of its professors concerning their research projects funding. Therefore, entrepreneurship had become a feature of American scientists even before the emergence of knowledge commercialization opportunities. Nowadays more and more universities are involved in academic entrepreneurship. In this sense, higher education in the USA is the leader and the model for all universities world-wide.

New institutional organizations within an innovative environment, such as business incubators, scientific centers and parks, technology networks and platforms, convergence laboratories, and various other associations, become a source of economic activity and international exchange within the innovation environment. The innovative "Triple Helix" model inspires its followers to generate new knowledge, develop cooperation in science, and initiate joint ventures (see Fig.2).
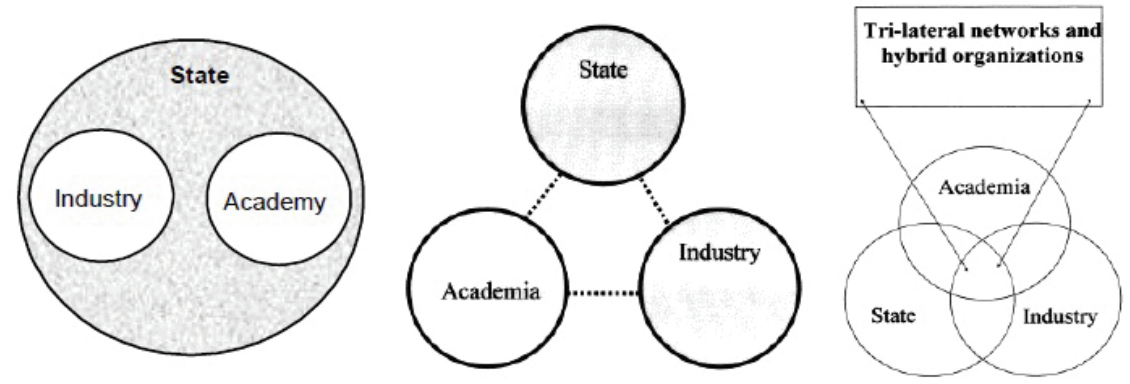

Fig. 1. From the Statesman and Laissez-faire the Triple Helix (source: adapted of Edskowitz \& Leydesdorff 2000: 3) 


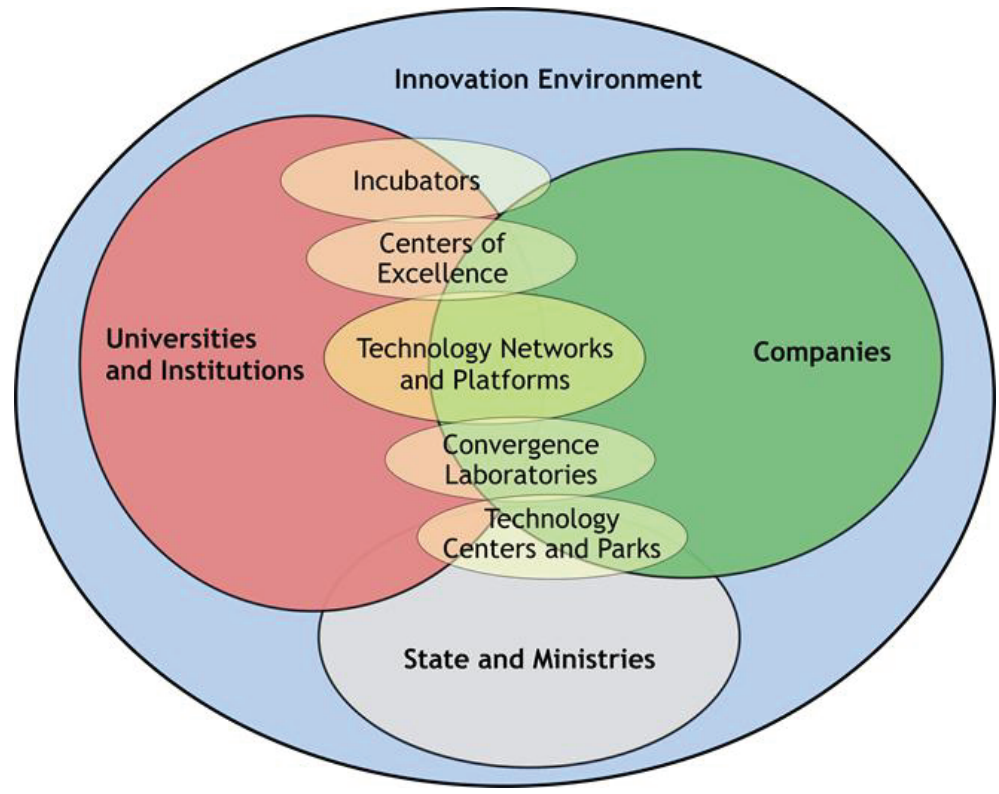

Fig. 2. Links between the state, the private sector and universities (source: ICT Technology Network http://www.ict-slovenia.net/eng/about-technology-network/triple-helix)

So, as a result of our study of American and Ukrainian scientific findings, we concluded that a university in the XXI century should be: innovative, and have high standards of education and scientific research; conscious of its mission, values and opportunities; well-funded in order to provide high-quality education and research. This model is ideal, but our awareness of the ways to reform higher education gives hope that the voice of the academic community will be heard and supported by the government, and philanthropists, as well as professors and teaching staff of universities.

\section{Historical Perspective of Endowment in Educational Fundraising}

Proper definitions are critically important to the analysis of ideas, for the meanings assigned to words fundamentally shape and direct the path of discourse. There is more than one definition of an endowment. Webster's conception of an endowment is as follows: 1) a large amount of money that has been given to a school, hospital, etc., and that is used to pay for its creation and continuing support; 2) the act of providing money to create or support a school, organization, etc.; 3) a per- 
son's natural ability or talent. Wikipedia defines a financial endowment as a donation of money or property to a not-for-profit organization for the ongoing support of that organization. Usually the endowment is structured so that the principal amount is kept intact while the investment income is available for use, or part of the principal is released each year, which allows for the donation to have an impact over a longer period than if it were spent all at once. An endowment may come with stipulations regarding its usage. Financial Dictionary says that an endowment is any asset donated to and for the perpetual benefit of a non-profit institution. The donation is usually made with the requirement that the principal remains intact and money earned from investing the principal be used for a specific purpose. Given these definitions, endowment might perhaps be best understood as a concept within the modern social sciences, at least as an educational fundraising tool for contemporary entrepreneurial university.

The history of charitable endowment giving dates back to the Roman Empire when in the 2nd century AD Marcus Aurelius founded endowed chairs for four teachers in Athens to start up schools of philosophy (Koester, 1995: 321-347). This practice was a role model for the rest of the progressive citizens of the empire, and resulted in establishment of a range of schools within the country. Endowment giving has a long subsequent history (see Tab. 1). Endowments come typically from private individuals, as foundations, corporations and governments usually give their gifts for current uses. The history of charitable endowment giving has encouraged the development of liberal arts, education, medicine, and more, for centuries.

Table 1. Brief Timeline of Charitable Endowment Giving (source: History, Culture, and Religion of the Hellenistic Age: 321-347; The Byzantine Empire: 18; History of Charitable Endowment Giving; The Department of Classical Studies University of Michigan; Women's Philanthropy on Campus: 6; 100 Years of Impact: Carnegie Endowment for International Peace)

\begin{tabular}{|l|l|l|}
\hline \multicolumn{1}{|c|}{ Date } & \multicolumn{1}{|c|}{ Representative } & \multicolumn{1}{c|}{ Description } \\
\hline $387 \mathrm{BC}$ & Plato, a Greek philosopher & $\begin{array}{l}\text { He founded the Academy in Athens, the first institu- } \\
\text { tion of higher learning in the Western world. } \\
\text { However, as part of a general policy of discrimination } \\
\text { against heretics, pagans, and other intellectual dissi- } \\
\text { dents, Justinian I confiscated the rich endowment of } \\
\text { the Academy in Athens, founded by Plato nearly } \\
\text { a thousand years earlier; and ordered its members to } \\
\text { cease teaching. But the closure of the school was } \\
\text { a temporary measure. The teaching of Plato's phi- } \\
\text { losophy in Athens during the Roman era went on } \\
\text { though with reduced endowments, till the 6 } 6^{\text {th }} \text { century. }\end{array}$ \\
\hline
\end{tabular}




\begin{tabular}{|c|c|c|}
\hline Date & Representative & Description \\
\hline 1136 & Bishop Henry de Blois & $\begin{array}{l}\text { The Hospital of St Cross to see to the needy was } \\
\text { established. }\end{array}$ \\
\hline 1502 & The Countess of Richmond & $\begin{array}{l}\text { Chairs at Oxford and Cambridge to teach divinity } \\
\text { were endowed. }\end{array}$ \\
\hline 1546 & $\begin{array}{l}\text { King Henry VIII (grandson of } \\
\text { the Countess of Richmond) }\end{array}$ & $\begin{array}{l}\text { Regius Professorships to teach five subjects including } \\
\text { civil law, divinity, Greek, Hebrew and physic were } \\
\text { established. }\end{array}$ \\
\hline 1643 & $\begin{array}{l}\text { Lady Mowlson } \\
\text { (Ann Radcliffe) }\end{array}$ & $\begin{array}{l}\text { She endowed a scholarship fund for sons of black- } \\
\text { smiths and farmers at Harvard, created just seven } \\
\text { years earlier. }\end{array}$ \\
\hline 1834 & Mary Lyon & $\begin{array}{l}\text { She was a pioneer in women's education in America, } \\
\text { founding in } 1834 \text { the Wheaton Female Seminary } \\
\text { which became Wheaton College and the Mt. Holyoke } \\
\text { Female Seminary in } 1837 \text { which became Mt. Holyoke } \\
\text { College. }\end{array}$ \\
\hline 1893 & Mary Elizabeth Garrett & $\begin{array}{l}\text { She donated the remainder of funds needed for the } \\
\text { new medical school at Johns Hopkins University } \\
\text { provided that the university agrees to admit women } \\
\text { on the same basis as men. }\end{array}$ \\
\hline 1901 & Mrs. Jane Stanford & $\begin{array}{l}\text { Her estate, valued in excess of } \$ 40 \text { million, was en- } \\
\text { dowed to the Leland Stanford Jr. University. }\end{array}$ \\
\hline 1906 & Harvard's class of 1881 & $\begin{array}{l}\text { A gift of } \$ 113,777 \text { was given by the alumni for sup- } \\
\text { port of their alma mater. }\end{array}$ \\
\hline 1910 & Andrew Carnegie & $\begin{array}{l}\text { Established the Carnegie Endowment for Interna- } \\
\text { tional Peace with a gift of } \$ 10 \text { million. It is an interna- } \\
\text { tional affairs think tank, a unique global network of } \\
\text { policy research centers in Russia, China, Europe, the } \\
\text { Middle East, and the United States. }\end{array}$ \\
\hline 1965 & $\begin{array}{l}\text { U.S. President Lyndon } \\
\text { B. Johnson }\end{array}$ & $\begin{array}{l}\text { The National Endowment for the Arts and the Hu- } \\
\text { manities was established to nurture American crea- } \\
\text { tivity and culture. }\end{array}$ \\
\hline late $1990 \mathrm{~s}$ & Darla Moore & $\begin{array}{l}\text { She was lauded for her gifts totaling } \$ 70 \text { million to } \\
\text { the University of South Carolina. }\end{array}$ \\
\hline 2001 & George Platsis & $\begin{array}{l}\text { He endowed } \$ 250 \text { thousand to the University of } \\
\text { Michigan in remembrance of his parents, Arthur and } \\
\text { Mary (Seiradakis) Platsis, both from Crete. Funds } \\
\text { from this endowment serve two main purposes: an } \\
\text { annual symposium and student prizes for original } \\
\text { work relating to the Greek Legacy. }\end{array}$ \\
\hline 2002 & Meg Whitman & $\begin{array}{l}\text { She gave } \$ 30 \text { million to her alma mater, Princeton } \\
\text { University. }\end{array}$ \\
\hline 2007 & $\begin{array}{l}\text { Alumna Barbara Dodd Ander- } \\
\text { son }\end{array}$ & $\begin{array}{l}\text { She contributed } \$ 128 \text { million to the George School, } \\
\text { an independent secondary school outside of Phila- } \\
\text { delphia. }\end{array}$ \\
\hline 2009 & An anonymous donor & $\$ 100$ million were given to colleges and universities. \\
\hline
\end{tabular}


Today philanthropy in Ukraine is regulated by the Law "On Charity and Charitable Organizations". According to this document, charity is considered to be “... a voluntary selfless donation made by individuals or legal entities for the purpose of provision of material, financial, logistical, and other kinds of assistance to beneficiaries" (Про благодійність та благодійні організації. Закон України 1997: 292). Under the conditions of market relations, when the amount of public funding of higher education institutions (HEIs) reduces, and the competition on the educational service market increases, there is an urgent need for the diversification of sources of income for universities (Worth, 2002). It is crucial to solicit various categories of donors, including alumni and their families, friends and associates, charity funds and companies. In a strategic sense endowment is the key mechanism of educational fundraising. It represents money or other financial assets that are donated to universities (typically by individual donors), and invested so that the total asset value yields an inflation-adjusted principal amount (Worth, 2002). Philanthropic motives are various (Yale University Office of Development). The key motive for alumni tends to be a desire to help their alma mater, to give thanks for the education they have received (Massy, 1990; Council for Aid to Education, 2010 in Drezner, 2011: 9). Foundations are primarily concerned with supporting research carried out in universities; in a broader sense they support research and education processes aimed at achieving certain goals which coincide with their own, for example, the training of a new generation of managers. Companies are interested in qualified young professionals, so they support educational programs that serve as a mechanism for creating a positive image of their companies among the target audience of students and graduates that sometimes results in their further recruitment. Businesses, especially in the industrial field, are also focused on conducting university-based research. Finally, support of institutions by large corporations is an example of public-private partnerships and, thus, it demonstrates the social responsibility of business. The motives of different categories of donors listed above determine the peculiarities of educational fundraising. Typically, $5 \%$ of endowment's revenue, called the spending rate, is used to fund day-to-day university operations as well as to upgrade university facilities, or to hire the best world educators (e.g. scholars such as Isaac Newton and physicist Stephen Hawking have both served as endowed professors; in fact, they both filled the very same endowed chair). Endowments in the educational system of the United States have become role models for the rest of the world. Leading American universities receive up to $30 \%$ of their budgets from endowments' revenues, which are channeled into student financial aid, payment for educational programs and improving the skills of their teaching staff, and funding the most promising 
research projects that will have the biggest impact on campus. It is important to point out that Harvard University endowment has been the largest for many years. The second position among the universities with the largest financial endowment is taken by Yale University (see Tab. 2). The main document that regulates the work of endowment funds in the US, is The Uniform Prudent Management of Institutional Funds Act (UPMIFA) ${ }^{1}$ passed in 2006, which replaced a similar law of 1972. The first endowment fund was created in the USA in 1649 to support Harvard University. Today it is one of the largest in the world: its assets exceed \$32 billion and provide 33\% of the university budget. According to the experts' opinions, the existing endowments of Ukrainian universities will need at least 10 years to be able to cover $10-15 \%$ of their annual budgets.

Table 2. A list of U.S. institutions of higher education with endowments greater than one billion dollars according to National Association of College and University Business Officers (NACUBO). For this list, short scale billions (thousand of millions) are used. (Source: National Association of College and University Business Officers (NACUBO). 2013. Retrieved 2014-04-18; National Association of College and University Business Officers (NACUBO). 2010. Retrieved 2010-01-29; National Association of College and University Business Officers. 2006-01-23. Retrieved 2013-02-01)

\begin{tabular}{|c|c|c|c|c|c|}
\hline $\begin{array}{c}\text { End of fiscal } \\
\text { year endow- } \\
\text { ment }\end{array}$ & & & & & \\
\hline School name (state) & $\begin{array}{c}1986 \\
\text { (billion } \\
\text { USD) }\end{array}$ & $\begin{array}{c}2005 \\
\text { (billion } \\
\text { USD) }\end{array}$ & $\begin{array}{c}2009 \\
\text { (billion } \\
\text { USD) }\end{array}$ & $\begin{array}{c}2013 \\
\text { (billion } \\
\text { USD) }\end{array}$ & $\begin{array}{l}\text { Percent of } \\
\text { alumni who } \\
\text { contribute to } \\
\text { university } \\
\text { endowment }\end{array}$ \\
\hline - Harvard University (MA) & $\$ 3,435$ & $\$ 25.473$ & $\$ 25.662$ & $\$ 32.334$ & $47 \%$ \\
\hline - Yale University (CT) & $\$ 1,739$ & $\$ 15.224$ & $\$ 16.327$ & $\$ 20.780$ & $45 \%$ \\
\hline - Stanford University (CA) & $\$ 1,502$ & $\$ 12.205$ & $\$ 12.619$ & $\$ 18.668$ & $39 \%$ \\
\hline - Princeton University (NJ) & $\$ 1,934$ & $\$ 11.207$ & $\$ 12.614$ & $\$ 18.200$ & $64 \%$ \\
\hline - Massachusetts Institute of Technology & $\$ 0,971$ & $\$ 6.712$ & $\$ 7.982$ & $\$ 11.005$ & $46 \%$ \\
\hline
\end{tabular}

${ }^{1}$ The Uniform Prudent Management of Institutional Funds Act (abbreviated UPMIFA) is a uniform act that provides guidance on investment decisions and endowment expenditures for nonprofit and charitable organizations. As of 2012 UPMIFA is the law in 49 states, the District of Columbia and the U.S. Virgin Islands. Neither Pennsylvania nor Puerto Rico has adopted UPMIFA. The major change in UPMIFA compared to the previous model law (the Uniform Management of Institutional Funds Act) is that it replaces a requirement that nonprofits cannot spend below the original value of contributions or "historic dollar value" (HDV) with a new requirement that their investing and spending will be at a rate that will preserve the purchasing power of the principal over the long term. The predecessor to UPMIFA, called the Uniform Management of Institutional Funds Act (UMIFA), was approved by the National Conference of Commissioners on Uniform State Laws (NCCUSL) in 1972 and was enacted by 47 states. Under UMIFA a charity could spend from an endowment fund up to the amount of appreciation above the HDV, but could never spend below HDV. 
Better market conditions helped boost college-endowment gains for the 2013 fiscal year, according to data released by NACUBO-Commonfund Study of Endowments, which is based on June 30,2013, survey data. The list is dominated by private schools, which is to be expected because they are smaller than public universities and more reliant on fund-raising.

Though the advantages of endowments may seem obvious, they have some serious drawbacks. According to Kim Klein there are also some philosophical concerns about endowments that are discussed in his work "Fundraising for Social Change" (Klein, 2011: 319-328). Moreover, large-scale fundraising strategies are loaded with details, so there is not much room for mistakes or carelessness. A university is ready for endowment projects when it completed the tasks for launching an endowment campaign that includes a number of steps: 1) set a goal; 2) create the gift range chart; 3) create the timeline; 4) form a solicitation team; 5) compile and organize the list of prospects; 6) solicit the gift (Klein, 2011: 329-337). Thus, having a better understanding of the mechanics and means in which universities solicit support will help development officers (fundraisers) become more sophisticated and engage more individuals in giving.

\section{Conclusion}

A lot more research should be done in order to optimize the development of endowments in Ukrainian universities, namely in the area of legislative, organizational and contextual foundations of financial endowments as a tool of educational fundraising. Particular attention should be paid to the issue of how best to solicit potential donors, since it is one of the milestones of the foundation and development of endowments. This is a new and so far underdeveloped research area for Ukrainian universities. In this regard, the experience of the world's largest universities, in particular the US ones that have decades of successful practice, is particularly valuable for us. To be a success in that undertaking, an efficient infrastructure should be created that will ensure effective communication and interaction with students, alumni, corporations and foundations. A bright example of successful interaction between alumni and university is Princeton, which has attained the best results in this area (see Tab. 2).

Thus, building a system of educational fundraising at Ukrainian universities and the establishment of endowments is capable for becoming an impetus for suc- 
cessful and innovative educational and research development, but it sets new large-scale challenges for an educational institution. It is reasonable not only to identify new forms and ways of functioning and development for the university, and to learn to raise resources from alumni, companies and foundations, but also to create new decision-making mechanisms. Eventually, university development officers should work out methodological tools to manage endowments as longterm investment resources.

Given the fact that modern education is a "strategic resource of socioeconomic, cultural and spiritual development of our society, improving people's welfare, protection of national interests, strengthening of international credibility and creation of a positive image of our country, establishing the conditions for self-realization of each individual" (Національна стратегія розвитку освіти в Україні на 2012-2021 роки, 2013: 86), we consider educational fundraising to be an essential tool for development of the national system of higher education. It is especially vital in the process of integration of Ukraine into the European and global educational area. In the modernization of the national philanthropic experience in the context of advanced technology and world standards of charitable initiatives, we must also take into consideration the progressive approaches of the US universities based on the global human culture of philanthropy.

Eventually, universities in Ukraine will have to implement the best practices of American universities when it comes to fundraising, or risk falling further behind in the development of their education and research programs. This entails trying to raise significant amounts of money to counter a drop in government funding. Philanthropic support of the university enables it to better meet the challenges facing higher education today. Contributions from companies, foundations and private citizens, such as alumni, friends, parents, and faculty to the university's research and education through fundraising help it build on its rich history while providing world-class opportunities for today's students. Philanthropy in higher education helps attract and retain the finest faculty, increase scholarship support, create and endow research centers, ensure state-of-the-art resources, expand programming, and secure the long-term financial health of the university by boosting its endowment. Well-invested and strong endowments allow donors to create a permanent legacy, and unleash the unlimited potential of education, plus they grow significantly over time. Moreover, American universities value this legacy in education, passed down from generation to generation. For instance, Alumni Association Scholarships are created to support legacy students, who have a mother, 
father, or grandparent with a degree from this university. Scholarship recipients are selected on the basis of their academic records, involvement in leadership and community service activities, and demonstrated financial need. According to the sources researched we came to the conclusion that fundraisers help create the bridge between the mission of a university and the marketplace.

\section{Literatura}

Browning R. (1992). The Byzantine Empire (Revised Edition). CUA Press.

Chao J. (2002/2008). What is Chinese American Philanthropy? [In:] A. Walton and others (Eds.), Philanthropy, volunteerism and fundraising in Higher Education. Boston.

Drezner N.D. (2011). Philanthropy and Fundraising in American Higher Education. "ASHE: Higher Education Report": Volume 37, Number 2.

Klein K. (2011). Fundraising for Social Change. Jossey-Bass A Wiley Imprint, 6th Ed.

Koester H. (1995). History, Culture, and Religion of the Hellenistic Age. Walter de Gruyter.

Massy W.F. (1990). Endowment: Perspective, Policies, and Management. Washington (DC).

Worth M. (2002). New Strategies for Educational Fundraising. New York.

Rediscovering America: Thirty-five Years of the National Endowment for the Humanities (2001). Washington (DC).

Women's Philanthropy on Campus: A Handbook for Working with Women Donors (2009). Women's Philanthropy Institute at the Center on Philanthropy at Indiana University.

Болонський процес у фактах і документах (Сорбонна-Болонья-Саламанка-Прага-Берлін) / Упорядники: Степко М. Ф., Болюбаш Я. Я., Шинкарук В. Д., Грубінко В. В., Бабин І. І. Тернопіль: Вид-во ТДПУ ім. В. Гнатюка, 2003. - 52 с.

Національна доктрина розвитку освіти (витяг). Затв. Указом Президента України № 347/2002 від 17.04.2002 // Управління освітою. - 2005. - № 15-16. - С. 25-46.

Національна стратегія розвитку освіти в Україні на 2012-2021 роки // Вища школа. - 2013. № 2. - С. 86-106.

Про благодійність та благодійні організації. Закон України // Відомості Верховної Ради. 1997. - № 46. - ст. 292. (Із змінами, внесеними згідно із Законом №3091-III від 07.03.2002.

Źródła internetowe:

Council for Aid to Education (2010). Voluntary Support of Education 2009; http://vse.cae.org (Accessed: $17^{\text {th }}$ October 2014)

Etzkowitz H., Chunyan Zhou. Regional Innovation Initiator: The Entrepreneurial University in Various Triple Helix Models; the paper for Triple Helix VI conference, Singapore, May 16-18, 2007; www.triple-helix6.com (Accessed: $17^{\text {th }}$ November 2014).

Long H., History of Charitable Endowment Giving; http://charity.lovetoknow.com/history-charitableendowment-giving (Accessed: $28^{\text {th }}$ November 2014). 
National Association of College and University Business Officers; http://www.nacubo.org/ Research/NACUBO-Commonfund_Study_of_Endowments/Public_NCSE_Tables.html (Accessed: 14 ${ }^{\text {th }}$ November 2014).

The Bologna Process and the European Higher Education Area; http://ec.europa.eu/education/policy/ higher-education/bologna-process_en.htm (Accessed: 16 ${ }^{\text {th }}$ November 2014).

The Department of Classical Studies University of Michigan; http://www.lsa.umich.edu/classics/ community/platsisendowment (Accessed: $1^{\text {st }}$ November 2014).

The European Higher Education Area in 2012: Bologna Process Implementation Report. Education, Audiovisual and Culture Executive Agency (EACEA P9 Eurydice), 2012; http://eacea.ec. europa.eu/education/eurydice (Accessed: $24^{\text {th }}$ November 2014).

United Nations Development Programme in Ukraine; http://www.ua.undp.org/content/ukraine/ en/home.html (Accessed: $3^{\text {rd }}$ November 2014)

Yale University Office of Development; http://giving.yale.edu/ (Accessed: $26^{\text {th }}$ November 2014) 100 Years of Impact: Carnegie Endowment for International Peace; http://carnegieendowment. org/about/timeline100/index.html (Accessed: 25 $5^{\text {th }}$ October 2014).

Концепиія гуманітарного розвитку України на період до 2020 року; http://old.niss.gov.ua/ book/StrPryor/StPrior_12/3.pdf (Accessed: $5^{\text {th }}$ November 2014).

Національна стратегія розвитку освіти в Україні на 2012-2021 роки; http://www.mon.gov.ua/ images/files/news/12/05/4455.pdf (Accessed: $13^{\text {th }}$ November 2014).

\title{
Obdarzenie (kapitał docelowy) jako sposób pozyskiwania funduszy dla przedsiębiorczego uniwersytetu: amerykańskie doświadczenie a ukraińskie realia i perspektywy
}

\author{
Streszczenie
}

$\mathrm{Z}$ uwagi na przemiany społeczne $\mathrm{w}$ okresie ostatnich dziesięcioleci, wykształcenie wyższe zajmuje pozycję priorytetową w polityce państwowej większości krajów, zarówno rozwiniętych, jak i krajów rozwijających się. Każdy z krajów, który pragnie nadążać za zmianami cywilizacyjnymi, powinien traktować naukę i szkolnictwo wyższe jako dziedziny priorytetowe, a w konsekwencji poszukiwać najbardziej efektywnych narzędzi stworzenia warunków do przetrwania w czasie kryzysu, a także do dalszego rozwoju, realizacji swojej misji poprzez wytwarzanie nowej wiedzy, szkolenia specjalistów, świadczenia usług w zakresie edukacji, nauki i kultury, jak również wzmocnienia potencjału naukowego i gospodarczego swojego regionu i kraju. Zmiany zachodzące na rynku pracy są źródłem odpowiedniej zmiany w edukacji, która poddawana jest badaniom nie tylko ekspertów $\mathrm{z}$ tej dziedziny, ale także polityków, filozofów, menedżerów.

Celem niniejszego artykułu jest analiza aktualnych poglądów amerykańskich i ukraińskich naukowców na temat roli pozyskiwania funduszy (fundraisingu) w celu prowadzenia działalności edukacyjnej w warunkach globalizacji, w kontekście swoistości misji społecznej przedsiębiorczego uniwersytetu. W tym aspekcie amerykańscy naukowcy analizują problem autonomii uniwersyteckiej z jego „wnętrza”, ponieważ pracują w tym środowisku; rezultaty ich badań są cenne dla uniwersytetów ukraińskich, które poszukują nowych doświadczeń w tym zakresie. 
Reguły postindustrialnego społeczeństwa oraz edukacji masowej i kulturalnej tworzą środowisko, w którym uniwersytet powinien zostać aktywnym podmiotem gospodarczym. Ani na Ukrainie, ani nawet w Stanach Zjednoczonych w najbliższej przyszłości szkoły wyższe nie pozyskają z funduszy państwowych środków wystarczających do zabezpieczenia swoich potrzeb oraz do realizacji wizji i misji uczelni. Przy tym jedynie najbardziej prestiżowe uczelnie, uznani liderzy na rynku krajowym, uzyskują stałe wsparcie finansowe. Globalizacja staje się bardziej zdecentralizowana i rozpowszechnia się za pośrednictwem regionalnych sieci uniwersytetów, do obowiązków których należy tworzenie kompetencji zawodowych, intelektualnych, moralnych i osobistych, które uosabiają wizję ośrodku akademickiego. Do składników misji uniwersytetu należą dialogiczność, zdolność wyrażania własnej tożsamości i poszanowanie tożsamości innych. Obowiązkiem wyższych uczelni jest upowszechnianie wiedzy, przygotowanie społeczeństwa do odbierania informacji. Stąd konieczność zmiany kultury akademickiej, zmniejszenia jej izolacji i wewnętrznego wyłącznie zaangażowania. Dialog społeczny jest niezbędnym warunkiem rozszerzenia powiązań środowiska akademickiego z otoczeniem. Istotnym problemem $\mathrm{w}$ dniu dzisiejszym jest słabe przygotowanie studentów do samodzielnego rozwiązywania problemów. Obecnie, przepływ wiedzy z uniwersytetów do społeczeństwa ma charakter jednostronny. Dlatego też zyskuje uznanie pojęcie „zaangażowany uniwersytet”, które pochodzi ze Stanów Zjednoczonych. Warunkiem jego istnienia jest partnerstwo, obustronny kontakt oparty na wzajemnym szacunku, wykorzystanie zasobów akademickich w celu zaspokojenia potrzeb społeczności. Takie „włączone” uniwersytety są w stanie szybciej reagować na zmiany zachodzące w społeczeństwie. Praktyka światowa udowadnia, że jednym z najbardziej skutecznych schematów rozwoju uniwersytetu jest system „potrójnej helisy”, a mianowicie „uniwersytet - przemysł - administracja”, zaproponowany przez H. Etzkowitza. Właśnie uniwersytet przedsiębiorczy odzwierciedla nowy model zorientowanego na rynek ośrodku akademickiego. Staje się bardziej powiązany z konsumentem wiedzy, co integruje go z gospodarką rynkową. W ten sposób kapitalizacja wiedzy stanowi podstawę nowej misji uniwersytetu. W USA uniwersytet przedsiębiorczy istnieje na warunkach sumarycznej odpowiedzialności każdego z profesorów za finansowanie swoich naukowo-badawczych projektów. W konsekwencji przedsiębiorczość stała się swoistą cechą amerykańskich naukowców, zanim pojawiła się możliwości komercjalizacji wiedzy; aktualnie coraz więcej uniwersytetów przyjmuje model akademickiej przedsiębiorczości. W tym kontekście można uznać, że ośrodki akademickie w USA są liderami i wzorcami do naśladowania dla wszystkich uniwersytetów.

Po przeprowadzeniu analizy porównawczej prac naukowych amerykańskich i ukraińskich naukowców można dojść do wniosku, iż uniwersytet XXI wieku powinien dbać o wysoką jakość edukacji, prowadzić badania naukowe na najwyższym poziomie, posługiwać się innowacyjnymi technologiami; być świadomym swojej misji, znaczenia i możliwości. Powinien także być finansowany w pełnym wymiarze, czyli posiadać wszystkie niezbędne zasoby umożliwiające realizację procesu kształcenia oraz prowadzenia badań naukowych na wysokim poziomie. Taki model jest idealny, trzeba w tym miejscu jedynie wyrazić nadzieję, iż głos wspólnoty akademickiej zostanie w tym aspekcie usłyszany w całym społeczeństwie. W warunkach globalizacji oraz w kontekście neoliberalnej ideologii współczesnych reform edukacyjnych dywersyfikacja źródeł finansowania jest aktualnym problemem w zarządzaniu jednostką naukową. Jeden ze sposobów rozwiązania tego problemu dostrzegamy w rozwoju działalności w zakresie fundraisingu, odnoszącego się do umiejętności zdobycia środków finansowych potrzebnych do zaopatrzenia w niezbędne materiały, urządzenia oraz wyposażenie techniczne jednostki naukowej działającej w zakresie edukacji, nauki, a także pomocy społecznej. Ten rodzaj działalności jest nowy dla ukraińskiego szkolnictwa wyższego, jednak biorąc pod 
uwagę jakościowo nowe warunki jej funkcjonowania i pozytywne doświadczenie światowe, ma na Ukrainie znaczne perspektywy. W związku z tym badania w ramach pedagogiki porównawczej powinny ogniskować się również na stanie, tendencjach i prawidłowościach rozwoju edukacji o zasięgu globalnym, regionalnym i lokalnym, porównywaniu międzynarodowego i krajowego pedagogicznego doświadczenia - również i w kontekście fundraisingu. Problem naukowy fundraisingu ma międzydyscyplinarny charakter, ponieważ znajduje się w granicach przedmiotowego pola trzech dziedzin współczesnej pedagogiki: zarządzania jednostką naukową, innowacji pedagogicznej i pedagogiki porównawczej (porównawczo-pedagogicznej amerykanistyki), co implikuje wieloaspektowy charakter analizy zakresu jego badań. Dotychczas jednak nie przeprowadzono zintegrowanych badań, podczas których ustalono by teoretyczne, treściowe oraz procesualne zasady działalności fundraisingowej na państwowych uniwersytetach USA - w odniesieniu do problemów dywersyfikacji źródeł finansowania jednostki naukowej w ukraińskim szkolnictwie wyższym.

Odpowiadając na potrzeby państwowej polityki rozwoju edukacji Ukrainy, uniwersytety dążą do opanowania współczesnych technologii innowacyjnych. Interesy narodowe Ukrainy wymagają jak najszybszego dołączenia jej do międzynarodowej wspólnoty, ukształtowania się jako wpływowego europejskiego państwa. Jak pokazuje doświadczenie, sukces przekształceń transformacyjnych, budowa demokratycznego społeczeństwa obywatelskiego są niemożliwe bez radykalnych zmian w systemie edukacji. Jednym z priorytetowych składników procesu dołączenia Ukrainy do wspólnoty światowej jest integracja kulturalno-oświatowa. Aktywny udział w realizacji tego zadania powinny brać ośrodki akademickie Ukrainy. Najszybsze dołączenie do światowej współpracy naukowej i oświatowej, uczestnictwo w międzynarodowych programach edukacyjnych - wszystko to otwiera dla ukraińskich wyższych uczelni drogę do pozabudżetowych źródeł finansowania. 